\title{
Esophageal Pharmacobezoar in a Patient with Achalasia: A Case Report
}

\author{
Hamid Tavakkoli ${ }^{1, *}$
}

1. Associate professor of Gastroenterology, Isfahan University of Medical Sciences, Isfahan, Iran

\section{* Corresponding Author:}

Hamid Tavakkoli, MD

Department of Gastroenterology, Isfahan University of Medical Sciences, Isfahan, Iran

Telefax: + 983136691510

Email: h_tavakoli@med.mui.ac.ir

Received: 22 Feb. 2019

Accepted: 04 Jun. 2019

\section{ABSTRACT}

A few cases with esophageal bezoar have been reported in achalasia. We describe here a rare case of esophageal pharmacobezoar after ingestion of ferrous sulfate capsules in a patient with achalasia.

A 29-year-old woman presented with severe dysphagia since five days earlier. She had history of achalasia since 3 years ago but had refused any treatment option. After about 3 weeks of ferrous sulfate capsules ingestion, she developed severe dysphagia and was referred to a gastroenterologist. Physical examination was unremarkable. A barium swallow revealed dilated esophagus and bird's beak appearance. Esophagogastroduodenoscopy (EGD) showed dilated esophagus and soft black color bezoar in distal part of esophagus. The bezoar was retrieved with basket. In the next endoscopic session, achalasia balloon dilation was successfully applied.

Ferrous sulfate capsules can cause pharmacobezoar in patients with achalasia. Esophageal bezoar should be considered in differential diagnosis of untreated achalasia and acute exacerbation of dysphagia.

\section{KEYWORDS:}

Achalasia, Esophageal bezoar, Ferrous sulfate

Please cite this paper as:

Tavakkoli H. Esophageal Pharmacobezoar in a Patient with Achalasia: A Case Report. Middle East J Dig Dis 2019;11:174-176. doi: 10.15171/mejdd.2019.145.

\section{INTRODUCTION}

Endoscopic evaluation of patients with long standing untreated achalasia may reveal esophageal remnants of foods and fibers. But, esophageal bezoar is a distinct entity. Esophageal bezoars are usually medications and/or phytobezoar in patients with motility disorders of esophagus. Bezoar in the esophagus is a rare condition and associated with structural or functional abnormalities of the esophagus. ${ }^{1}$ It may occur in patients with esophageal anatomical defects (e.g. diverticulum, hiatus hernia, and post gastric surgery). It may also occur in patients with some predisposing eating habits such as excessive consumption of persimmon (a fruit with a relatively high gum and pectin content). Critically ill patients on mechanical ventilator receiving tube feeding via nasogastric tubes and on sucralfate and antacids therapy are also at risk of developing esophageal bezoars. ${ }^{2-5}$ only a few cases of esophageal bezoar in achalasia have been reported. ${ }^{6,7}$ It is the first case report of pharmacobezoar with iron capsules in achalasia, to our knowledge. 


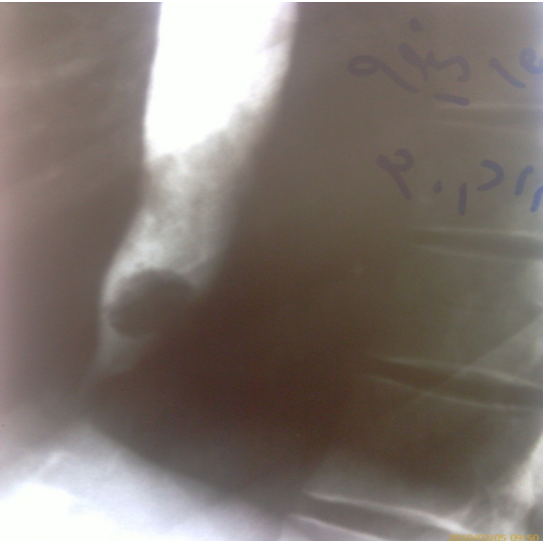

Fig.1: Filling defect in the distal part of dilated esophagus

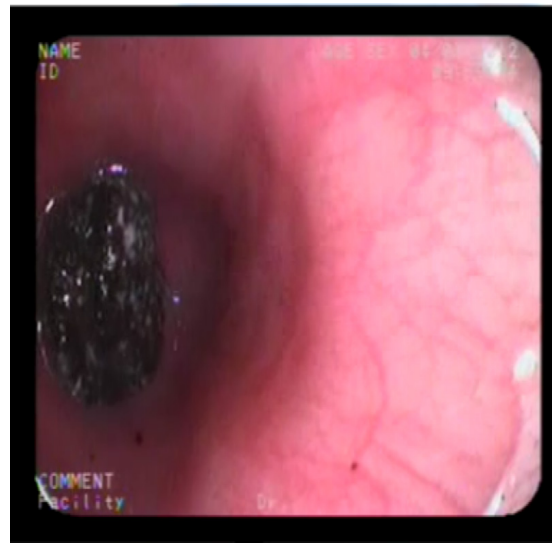

Fig.2: Esophageal bezoar in the distal part of dilated esophagus

\section{CASE REPORT}

A 29-year-old woman presented with severe dysphagia since five days earlier. She had history of mild progressive dysphagia since five years ago, which was diagnosed as achalasia according to barium swallow and esophagogastroduodenoscopy (EGD) 3 years ago, but she had refused any treatment option.

She sought medical attention because of fatigue, and general practitioner prescribed ferrous sulfate capsules for her about one month earlier. After about 3 weeks iron therapy, she developed severe dysphagia. She was referred to a gastroenterologist for further evaluation. The patient had no odynophagia, nausea, and vomiting. Physical examination was unremarkable.

On barium swallow esophagography, dilated esophagus and bird's beak appearance of lower esophageal sphincter with a filling defect in the distal part of esophagus were noted (figure 1). EGD showed dilated esophagus and elliptical shape, black color bezoar in the distal part of esophagus (figure 2). There was no ulcer or erosion in the esophagus. Lower esophageal sphincter (LES) was severely spastic.

At first, we tried to fragment and push the bezoar into stomach. But, because of high LES pressure and resistance and considering the risk of aspiration, this process discontinued. Finally, the bezoar was retrieved with basket.
Esophageal manometer was carried out and the results were compatible with the diagnosis of achalasia. In the next endoscopic session, achalasia balloon dilation (size $30 \mathrm{~mm}$ ) was successfully applied. She has been asymptomatic during the 3-year follow-up.

\section{DISCUSSION}

Our patient had prolonged history of progressive dysphagia in the setting of untreated achalasia, but presented with acute exacerbation of dysphagia, which was unusual. There is a case report of acute dysphagia as the first manifestation of esophageal phytobezoar in the literature of medicine. ${ }^{8}$ Also, acute presentation of esophageal bezoar as progressive dysphagia in a patient with achalasia has been reported. ${ }^{9}$ This may justify the uncommon presentation in our patient.

Two types of esophageal bezoars are medication bezoars and phytobezoars. Most medication bezoars tend to occur in critically ill patients on mechanical ventilator or in bedridden patients receiving a casein-containing enteral formula or sucralfate via a nasogastric tube. ${ }^{1}$ The present patient had a pharmacobezoar due to iron capsules prescription.

Barium swallow is a helpful diagnostic tool for esophageal bezoar; however, endoscopy should be considered the procedure of choice for diagnosis and treatment in such patients. If endoscopic removal fails, other treatment options include dissolution therapy and surgical evacuation. Surgical removal of esophageal bezoar is associated with 
high risk of morbidity and mortality. On the other hand, dissolution therapy is effective and inexpensive. Therefore, some authorities advocate dissolution therapy for esophageal phytobezoar as the first choice, if endoscopic removal was unsuccessful. ${ }^{1,7,10,11}$ We performed endoscopic retrieval of the bezoar successfully without complication.

\section{CONCLUSION}

Acute dysphagia may be the first manifestation of esophageal bezoar in patients with untreated achalasia and long standing symptoms. Supplemental iron consumption may cause esophageal pharmacobezoar. Endoscopic removal is the treatment of choice.

\section{ETHICAL APPROVAL}

There is nothing to be declared.

\section{CONFLICT OF INTEREST}

The author declares no conflict of interest related to this work.

\section{REFERENCES}

1. Kim KH, Choi SC, Seo GS, Kim YS, Choi CS, Im CJ. Esophageal bezoar in a patient with achalasia: case report and literature review. Gut Liver 2010;4:106-9. doi:10.5009/gnl.2010.4.1.106.

2. Lartigue C, Karayan J, Beau P, Kaffy F. [Esophageal bezoar resulting from nasogastric enteral feeding in an intensive care unit]. Ann Fr Anesth Reanim 2001;20:374-7. doi:10.1016/S0750-7658(01)00380-X.

3. Kise Y, Aihara R, Chino O, Yamamoto S, Hara T, Nishi T, et al. Sucralfate-formed esophageal bezoar detected following sudden vomiting. Endoscopy 2006;38 Suppl 2:E70. doi:10.1055/s-2006-944712.

4. Munsell WP, Walker EA Jr. Persimmon bezoar in an epiphrenic esophageal diverticulum with endoscopic removal. Gastrointest Endosc 1973;20:74-5.

5. Qureshi SS. Esophageal bezoar in a patient with normal esophagus. Indian J Gastroenterol 2005;24:38.

6. Shah SW, Khan AA, Alam A, Butt AK, Shafqat F. Esophageal bezoar in achalasia: a rare condition. $J$ Clin Gastroenterol 1997;25:395-6.

7. Liang JJ, Murray JA. Esophageal bezoar in the setting of achalasia. Dis Esophagus 2016;29:686. doi: 10.1111/dote. 12072 .

8. Reissman P, Fich A, Eid A, Rivkind A. Esophageal phytobezoar causing acute dysphagia: a rare complication of gastric bezoar. J Clin Gastroenterol 1994;18:159-60.
9. Goel AK, Seenu V, Srikrishna NV, Goyal S, Thakur KK, Shukla NK. Esophageal bezoar: a rare but distinct clinical entity. Trop Gastroenterol 1995;16:43-7.

10. Gupta R, Share M, Pineau BC. Dissolution of an esophageal bezoar with pancreatic enzyme extract. Gastrointest Endosc 2001;54:96-9. doi:10.1067/ mge.2001.115318.

11. Yaqub S, Shafique M, Kjæstad E, Thorsen Y, Lie ES, Dahl V, et al. A safe treatment option for esophageal bezoars. Int J Surg Case Rep 2012;3:366-7. doi: 10.1016/j.ijscr.2012.04.008. 